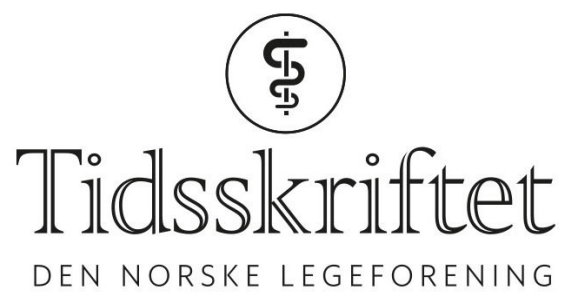

\title{
Rettelse: Hvor forskjellige kan generiske legemidler være?
}

RETTELSE

EVA SKOVLUND

Tidsskr Nor Legeforen 2019; 139. doi: 10.4045/tidsskr.19.0383.

I Tidsskriftet nr. 16/2019 på s. 1581 skal benevningen på y-aksen i figur 1 være Studie.

Vi beklager feilen, den er rettet på nett.

Publisert: 15. november 2019. Tidsskr Nor Legeforen. DOI: 10.4045/tidsskr.19.0731

(C) Tidsskrift for Den norske legeforening 2020. Lastet ned fra tidsskriftet.no 